\title{
Sarah's Lack of Love: A Lacanian Reading of Love, Again
}

\author{
Xiuhua $\mathrm{Li}^{1, \mathrm{a}^{*}}$ and Liyang Zong ${ }^{2, \mathrm{~b}}$ \\ ${ }^{1}$ Technology College, State Grid of China \\ ${ }^{2}$ The Library, Shan Dong University, China \\ afallingsnow201007@163.com, ${ }^{\mathrm{b}} \mathrm{Ixh} .1234560 @ 163 . c o m$
}

Keywords: lack of love, theory of three registers, the imaginary, the symbolic.

Abstract. Based on a Lacan's reading of the lack of love of Sarah, the heroine of Love, Again, the paper argues that the psychological transition from the imaginary to the symbolic is the underlying cause of Sarah's lack of love, and that it is the lack of love that helps Sarah re-enter the symbolic world and make progress on a higher level.

\section{Introduction}

Sarah is the protagonist of Doris Lessing's latest novel Love, Again. She is sixty-five-year-old, long widowed woman, who unexpectedly falls in love and struggles to maintain her sanity. No matter how great she looks or how charming she is, Sarah has not been in love in decades and still doesn't reach love in the end of the story.

Sarah's lack of love has won a lot of sympathy from readers and literary critics. Many critics have made social or gender analyses of her lack of love. Some of them argue that the lower status of women is responsible for their failure in fulfilling their love and through the love story of Sarah, Lessing sharply "declares her resistance to the many forms of cultural wrong endured by women" [1]. Others suggest that the author "has mainly focused on efforts by individuals to resist society pressures toward marginalization and acculturation" [2], for it is the society's refusal to agree with the love between old women and young men that leads to Sarah' s lack of love.

Of course, the cultural and social factors are of enormous significance in shaping human behavior. However, an individual's choice is determinative of his/her fate. Just as existentialist philosophers suggest, individuals are responsible for their choices of value systems through behaviours [3].Based on Lacan's Psychoanalysis Theory, the paper attempts to put forward a psychological explanation for Sarah's lack of love, beginning with an attempt to define the key words love and lack of love and to introduce Lacan's theory of three registers, and then presenting a psychoanalysis of Sarah's lack of love referring to Lacan's theory. Through the analysis, the paper argues that Sarah's psychological transition from the imaginary to the symbolic results in Sarah's lack of love, and this lack of love is not only the premise that Sarah becomes a cultural being but also the condition that drives Sarah to persist love, to make progress on a higher social level.

\section{Definitions of "Love" and "Lack of Love"}

Doris Lessing is regarded as one of the most celebrated and distinguished writers of our time. She has written candidly about the inner lives of women, and was awarded the Nobel Prize in Literature in 2007. Her latest novel Love, Again is specifically about women and unresolved passion —and about women and unrealized love.

The novel tells the story of a 65-“year-old woman who struggles with a sudden upsurge of love long thought dead. Widowed for many years, with grown children, Sarah is a writer who works in the theater in London. During the production of a play, she falls in love with a seductive young actor, the beautiful and androgynous 28-year-old Bill, and then with the more mature 35-year-old director Henry. Finding herself in a state of longing and desire that she had thought was the province of younger women, Sarah is compelled to explore and examine her own personal history of love, from her earliest childhood desires to her most recent obsessions... 
Before entering the text of the novel, I will attempt to define "love" and "lack of love", the key words in the novel and in my paper. Love really exists in the world and people usually express their love through praising: "Love is Mom's kiss and Dad's pat. Love is sweet roses to a lover and tender caresses to a child. Love is the tree of friendship. Love is mutual understanding and support” ....But what love is is one of the most difficult questions for the mankind. The definition of "love" is often tied to emotion. For example, love is defined as a perception of human emotions that inflames the sense of affection and sexual attraction [4]. However, for Lacan, love is the desire to fulfill a lack. Lacan points out that "love” is, in essence, a futile chasing after something that doesn't exist [5] . Based on Lacan's view of love and the plot of Love, Again, I define "love” for Sarah as demand to be loved by and unified with the men she desires for, and further define" the lack of love" as the fact or condition of her demand for love not being satisfied.

\section{Lacan's Theory of Three Registers.}

Lacan, Jacque is the most influential French thinkers of the 20th century. In the 1950s, he interpreted Freud's ideas and put forward his own theory of psychoanalysis on the basis of structural linguistics and anthropology. His psychoanalysis doctrine and philosophy ideas have affected the entire Western academics.

Lacan's one main contribution to psychoanalytic thought lies in his theory of three registers. He analyzes the psychological development of from infant to adult and presents three concepts: need, demand and desire that roughly correspond to 3 phases of development, or 3 fields in which humans develop- the Real, the Imaginary, and the Symbolic..

The Real. The Real, as the phase of need, lasts from birth till somewhere between 6 and 18. In this phase the infant is something inseparable from its mother. Driven by NEED, it needs food, comfort/safety, or to be changed, etc., all of which can be satisfied by an object. The real is the state of "nature," which has to be broken up in order for culture to be formed.

The Imaginary. When between 6 and 18 months old, the baby starts to be able to distinguish between its body and everything else in the world. The awareness of separation, or the fact of otherness, creates a sense of loss. The baby then demands a reunion, a return to that original sense of fullness that it had in the Real. At this point, the baby shifts from having needs to having DEMANDS, which is always for recognition or love from others.

This is where Lacan's MIRROR STAGE happens. What the child anticipates is a sense of self as a unified separate whole. Eventually, this entity the child sees in the mirror is a whole being, which is designated by the word "I" or the subject. By doing this, according to Lacan, the baby imagines a self that has no lack, no notion of absence or incompleteness.

The Symbolic. At some point that the child moves "from insufficiency to anticipation"(Lacan, 1977) in the mirror, he gets the sense of "other" and the concept of self, a concept which relies on one's misidentification with this image of an other. The "little other" illustrates for the child the idea of lack, of loss, of absence, which form the structures of symbolic order. So, in the Symbolic, there is a structure (or structuring principle) of Otherness, and a structuring principle of Lack, which is the gateway to the Symbolic order.

In the Symbolic order, the Other (capital O) is a structural position that everyone is trying to get to, to merge with, in order to get rid of the separation between "self" and "other." But, as the position of center, the Other can't be merged with. So the position of the Other creates and sustains a ever-ending LACK, which Lacan calls DESIRE. By definition, desire can never be fulfilled. Lacan further gives an idea of the unconscious which is "structured like and produced by language at the point of the subject's entry into the Symbolic Order"[6]. Thus, the Lacanian subject becomes a subject with two parts/aspects: consciousness/ego and the unconscious, the latter of which is "the discourse of the Other" and the home of the subjec[6].

The Symbolic realm, which is marked by the concepts of desire, is the realm we have to enter in order to become social being. This psychological transition of from the imaginary into the symbolic produces social subjects and shapes human progress. 


\section{Toward Love in the Imaginary}

At the beginning of the novel, Sarah, as an old woman who has thrown her energy into writing, has entered the symbolic order. However, Just as Lacan points out, the mirror stage is not limited to early childhood, but the permanent representative of the main structural contradictions of the subject who is always captured by her own image[6]. So, from the details of the novel, we still can figure out Sarah's psychological state of "mirror stage", or of the imaginary, in which Sarah is drifting toward love through fantasy.

One detail of the story is Sarah's blocked memories of a childhood in which her mother preferred her brother, Hal, and denied her affection. From her memories of childhood, we can see that Sarah was a spiritual orphan when very young and the lack of mother love drives her demand to be loved by the opposite sex. Sarah experienced her "first love" when she was only six and had more than her share of boyfriends when she was a young woman. Up to that time, Sarah lived in realm of the imaginary, which is "associated with the desire and figure of the Mother" [6] according to Lacan.

Sarah's demand for love wasn't satisfied, and on the contrary her misfortunate love stories seemed to be "mysteriously disfiguring and deforming her" [7]. For Sarah, Love, which represents the primitive missing, is always elusive and impossible to be fulfilled. After her husband, Alan, died when she was 35, Sarah didn't fell in love again and lived a calm and reasonable life. Sarah's demand for love has been replaced by small others, such as demand to be respected or admired in the society. Therefore, Sarah makes great efforts to get more great achievements through self-efforts and win other's respect and admire. Everyone thinks of Sarah as "sensible". For the past 20 years, Sara has thrown all her energy into writing plays and running a small theatre group in London, living a quiet life devoid of the upheavals of romance”. Based on Lacan's theory, we can conclude, through Sarah's examination of her own personal history of love, that Sara has long lived in the symbolic world, a realm which is thought "to subordinate and repress the pre-symbolic imaginary" [6]

However, all this abruptly changes when Sarah begins to stage an avant-garde operatic play concerning the enigmatic Julie Vairon, a beautiful, mysterious and artistically gifted young quadroon of the early nineteenth who was romantically involved with two Frenchmen, was abandoned twice and eventually committed suicide. Julie's own eroticism seems to be working its magic to make Sarah realize that there is a gap in her life. Troubled by Julie's troubadour music, haunted by fragments of memories of her own marriage, Sarah enters what Lessing calls "Julie's country," a mental state of readiness for love. Here, the theater, as an evasion of "the symbolic order", serves as a mirror that introduces Sarah into the imaginary world. The literature imagination unnoticeably reveals her demand for love, which is like the baby's demand to be filled by the other in the imaginary. "She was dissolved in longing"[8] Ms. Lessing (1997) writes. "She could not remember ever feeling the rage of want that possessed her now. Surely never in her times of being in love had she felt this absolute, this peremptory need, an emptiness that hollowed out her body, as if life itself was being withheld from her." [8]

Just as the baby tends to imagine himself as a whole in the mirror, Sara perceives herself as a complete woman possessing love in the theater. According to the plot, Sarah develops an intense friendship with her co-author, Stephen Ellington-Smith, a wealthy patron of the arts; she develops a terrible crush on the beautiful young man, Bill Collins, who plays one of Julie's lovers; she learns that the play's other male lead, Andrew Stead, is desperate to go to bed with her; and even Sarah herself marvels at her predicament and thinks: "In a group of chimps, the senior female is sexually very popular"[8].... In the theater, Sarah, madly pursued by three gorgeous and very sought-after men, seems to have come nearer and nearer to love and almost returned to the reunion. But, according to Lacan's concept of mirror stage, Sarah's demand for the completeness of self , or for the unity with others can never be satisfied, because that lack, or absence, the sense of "otherness", is the condition for the baby becoming a self/subject, a functioning cultural being[6] . In other words, Sara's concept of complete self in the mirror, known in psychoanalytic terminology as an "ideal ego" just relies on her misidentification with this image of the other, and her love experience in the theater, filled with sentiments and eroticism, is just an illusion or a fantasy. 
Although fantasy can never be fulfilled or confused with reality, it is still the necessary way in which Sara structures or organizes her desire. As Zizek(1995) puts it, "through fantasy, we learn how to desire" .Sarah enjoys living in the imaginary and through fantasy she gradually establishes an ideal self and drifts toward love that remains unsatisfied in the reality[9].

\section{Away from Love in the Symbolic}

Though sometimes dangling in her fantasy, Sarah is still afflicted with a cold eye, maybe called the unconscious according to Lacan theory, which leads her to re-examine herself and otherness and to return to the symbolic world through distancing herself from love.

Her misadventures in love at the age of 65 helps Sarah experience not only a sense of her lack of love and desire for love, but also a kind of delayed reaction to her ageing. Sarah suddenly becomes aware of the pain and agony of growing old and her lost attractiveness to the opposite sex. She struggles to accept her ageing face and body and her lost youth with great pain. For Sarah, the pain actually helps her to a greater understanding of herself: she is an old woman who will have to deal the problem of aging and the woman with complete love in the stage just relies on her imagination of love story .Such understanding discourages her from coming closer to love. Such understanding, in Lacan's view, is also the gate way for Sarah to return to the symbolic order which is premised on the idea of lack and absence.

At the same time, Sarah re-examine others around her and her relationship with them. She looks at those around her, who all seem much younger than her, and feels like "a miserable old ghost at the feast"[8]. Miserably, the men whom Sarah is falling in love with are young enough to be her sons. As far as Sarah senses, the men who are drawn to her but are ultimately not willing to enter into even a casual sexual relationship with her. In addition, young women around the young men further decrease Sarah's confidence in seeking love and leaves her more pain. When she sees Bill with a younger woman, we are told, "pain sliced through her": "Knives had nothing on this: red-hot skewers were more like it, or waves of fire" [8]. Such painful perception of others and her relationship with them discourage Sarah from approaching love. At the same time, once Sarah formulates ideas of others and her relationship with them, she begins to enter the higher stage: the symbolic realm.

In addition, Sarah is acutely aware of the symbolic order, the structural position in the symbolic realm. The symbolic order, according to Lacan, is a universal structure encompassing the entire field of human action and existence[6]. It is this universal structure that more powerfully propels Sarah to move away from love and return to the symbolic world. The social rule of the late 18th and early 19th centuries that well-matched social status is quite essential for marriage is responsible for Julie's lack of love, but no longer exists in Sarah's time. However, Sarah is still limited by another social rule that the society is reluctant to accept the love between old woman and young man, even though they agree more with the love between old man and young woman. In Sarah's time, the society looked on old women as invisible, "complete and unsexed" and it was unreasonable for a young man to marry an old woman. In Lacan's theory, such social rule and attitudes represents the big other, which functions as the way in which Sarah's unconscious is organized and, to a certain extent, as the way in which Sarah becomes a social being away from love in the special culture. Sarah enjoys her fantasy in the imaginary, while on the other hand, she has to choose to be accepted by the big other of the symbolic. In fact, just as Lacan points out, our desire, which we may believe to be most private and rebellious, is regulated, even commanded, by the big other through our unconsciousness, "the discourse of the other" [6].

In front of such a big other, which is both the embodiment of the social substance and yet also the site of the unconscious, Sarah has no choice but to choose to step away from her love in the fantasy and re-enter the symbolic order. 


\section{The Value of the Lack of Love}

Based on Lacan's psychological theory, Sarah's love to be unified with men is not properly her own but is created through fantasies and finally caught up or lost in cultural ideologies. In this sense, the lack of love is valuable, for it is the premise for Sarah to enter the symbolic world, which is also called the reality, and, more significantly, it is this condition that ensures Sarah to continue to persist her love and make progress on a higher level.

Just as Lacan does not encourage individuals to "follow the 'risky' path of unconditionally refusing to turn away from his or her own desire [10], the attainment of love through breaking the social order will not bring comforting resolution. Some of the characters, called the " héros" by Lacan, pursue their love "despite betrayal and the tumult of life" [10] but are still not guaranteed happiness: " Stephen's wife in the arms of her lesbian lover, merry young American actors homeward bound to "meaningful relationships," ambitious Sonia's vicious courtship of the hapless young theatre critic, Henry with his small son--nobody provides any image of requited love that is bound for anything but eventual pain" [8]. Julia is another typical character who chooses to steer away from the lack of love through death. Since the real doesn't exist, we cannot tell whether she can attain her love in the real. What we really know is that, in the real which is away from the symbolic and all other representations, there are no more than attempts to persist love and cherish hope.

In contrast, Sarah, brilliantly aware of the value of lack, unconsciously keeps away from love rather than defying the symbolic order to attain the fantastic love in reality. Sarah refuses to accept love presented by the men whom she desires more strongly in her dream. Through the lack of love, Sarah realizes her persistence of love in compliance to the social order, which is the social and cultural existence of individuals. Since she has achieved the harmony between her persistence of love and the symbolic order, the social refusal to accept the love between old woman and young man is no long a pain bind for Sarah, because, however old she is, she will can keep away from love, thus allowing her love to persist her demand for love and enjoying her real life. Through her persistence of demand for love, Sarah has lifted her spirit on a higher social and cultural level and become a woman who cherishes desire "that exists beyond lack and limitation and that involves a sort of ecstasy of being” [11].

\section{Conclusion}

Driven by her primitive missing, Sarah has long demanded for love but not achieved love in the reality. Her misadventure at 65 years old drives her to drift toward love through fantasy in the imaginary order, while her unconsciousness propels her to keep distance from love imaginary in the symbolic order. In the end she peacefully accepts her lack of love, through which she becomes a cultural being. Based on the above psychoanalysis of Sarah's lack of love, it can be concluded that Sarah's move of her psychological involvement form the imaginary order into the symbolic order leads to her lack of love, a lack which ensures her existence and progress in reality. Such psychological explanation of Sarah's lack of love sheds new light on the way we organize our desire and existence, that is, we should obey the social validity, persist our desire through lack and process our social existence, a more advanced social being that has an awareness of human isolation and morality.

\section{References}

[1] Birch, Dinah. 1996. "Love, Again by Doris Lessing”. London Review of Books. .April,18.URL:<http://cgi.ebay.com/Love,-Again-by-Doris-Lessing-(1996)_W0QQitem Z350092332390QQcmdZViewItemQQimsxZ20080826?IMSfp=TL0808261336r3178.html>

[2] Larsen, Elizabeth. 2008 Doris Lessing. The Columbia Encyclopedia, Sixth Edition. Columbia: Columbia University Press. Beauvoir, Simone. 1989. The Second Sex. New York: Vintage. 
[3] Dobsevage, P. 1962. "L'Armlyse du destin: le Moi-Pontifex.” Philosophy and Phomenological Research, Vol. 23, No. 2, 301-302.

[4] Gallivanter, 2007. "Definition of Modern Life “. URL:< / danielfranklingomez.com/blog/2007/10/22/bon-jovi-the-radio-saved-my-life-tonight/ - 50k -.html>

[5] Lacan, Jacques. 1985. "God and the Jouissance of Woman.” In Mitchell, J. \& Rose, J. (Eds.), Feminine Sexuality: Jacques Lacan and the école freudienne. New York: W. W. Norton.

[6] Lacan, Jacques. 1977. Ècrits: A Selection. New York: W. W. Norton \& Company Inc,

[7] Rubenstein, Roberta. 2001. Feminism, Eros, and the Coming of Age. Frontiers: A Journal of Women Studies - Volume 22, Number 2, 2001, pp. 1-19

[8] Doris Lessing. 1997. Love, Again. Publisher: Harper Perennial

[9] Zizek, Slavoj. 1995. Looking Awry: An Introduction to Jacques Lacan through Popular Culture Cambridge,: The MIT Press. Mary Klages [7] Information on http://www.weld.labs.gov.cn

[10]Capobianco, Richard and College, Stonehill. 2001 "Limit and Transgression: Heidegger and Lacan on Sophocles' Antigone” Review of Existential Psychology and Psychiatry, Vol. XXVI. No. $1,17-26$.

[11]Richmond, Raymond.2003. "A Guide to Psychology \& its Practice" Sexuality \& Love.. URL:< http://www.guidetopsychology.com/sex_love.htm. > 